A N N A L E S

UNIVERSITATIS M A R A E C URIE-SKŁODOW S A

LUBLIN - POLONIA

VOL. XXXIII, 2

SECTIO J

2020

Pavlo Tychyna Uman State Pedagogical University. Faculty of Engineering and Pedagogical Education, Ukraine

\title{
OLEH MALYSHEVSKYI
}

ORCID: 0000-0002-7653-7862

omalysh67@gmail.com

\section{The Impact of Education Informatization on the Process of Engineering Educators' Professional Becoming}

Wpływ informatyzacji edukacji na proces przygotowania zawodowego inżynierów-pedagogów

How to QUOTE THIS PAPER: Malyshevskyi, O. (2020). The Impact of Education Informatization on the Process of Engineering Educators' Professional Becoming. Annales Universitatis Mariae Curie-Skłodowska. Sectio J, Paedagogia-Psychologia, 33(2), 95-102. DOI: http://dx.doi.org/10.17951/j. 2020.33.2.95-102.

\section{SUMMARY}

The article reveals the influence of education informatization on the process of computer engineering educators' professional becoming. It is substantiated that at present education informatization plays the role of a socio-cultural mechanism influencing the formation of an active, enterprising, and mobile specialist in the field of vocational education. It is established that the growth and complexity of social, economic, and professional information require the computer engineering educator to be able to adapt quickly and effectively to new conditions in the labour market. It actualizes the social need for the purposeful formation in such professionals of information and communication skills implying the achievement of professional self-improvement, self-determination, and self-positioning.

Keywords: education informatization; information and communication technologies; computer engineering educators; information and communication competences; psychological and pedagogical competences

The relevance of our study is brought about by the identified social contradiction that manifests itself in the social need arising in computer engineering educators to have a certain level of information and communication competence. It is caused by the general informatization of society and the insufficient satisfaction of this need by modern professional education. That is, there is a contradiction be- 
tween social demands and the satisfaction of these requests by higher vocational education.

The information society involves a new, qualitatively higher level of productive forces as compared to the industrial society (Machlup, 1962; Toffler, 1983). At the same time, Mikhaylevich (1989, p. 5) believes that the basis of social dynamics in society is comprised not of "traditional material resources, but of information (intellectual) resources - knowledge, science, organizational factors, people's intellectual capabilities, their initiative, and creativity". Informatization involves, first of all, the restructuring of social life based on the use of reliable, comprehensive, and modern knowledge in all socially significant types of human activity. Informatization as a material process lies in building the infosphere which is the global infrastructure of information acquisition, storage, accumulation, processing, and transmission media. In society, it is analogous to the central nervous system. The global computerization and informatization of society, first of all, influence the personal culture development level and modern culture in general (Mikhaylevich, 1989).

Dzhyncharadze notes that modern culture is filled with the content of the society that upholds it, namely, "post-industrial society", "mass media society", "information society". The main attribute of such societies is their social and cultural nature. The high level of new information technology determines the appropriate level of cultural development. It is about culture as a universal phenomenon that includes both work and professional culture (Dzhyncharadze, 1997, p. 174).

The leading countries of the world recognize the informatization of society as an important factor in national development. Ramskyi (2002) emphasizes that the decisive role in the informatization of society belongs to education informatization as a process aimed at improving education quality, as well as the elaboration, implementation, support, and development of new information technology in all types of educational activities. He argues that the process of education informatization has led to the need to understand the information culture, not only as a habitual ability to use the full range of information technology in one's daily work and life but also as a special thinking style (Ramskyi, 2002). Zhaldak and Ramskyi (2010) stress that educational process informatization should be pedagogically appropriate, theoretically and experimentally justified. It will help to solve one of the important social problems - the problem of population employment.

Education informatization creates prerequisites for the widespread implementation of psychological and pedagogical developments that provide a transition from the mechanical acquisition of factual knowledge to mastering skills needed for the independent acquisition of new knowledge. It gives a real opportunity to increase the scientific character of pedagogical experiment methods, 
maximally approach its methods and organizational forms to scientific experimental and research methodology, and provides an introduction to modern methods of working with information, educational activity intellectualization (Robert, 1991).

Regarding the informatization of education, academician Yershov (1998) noted that the real way of the integration of the latest information technology, computer equipment and various educational subjects into this area is a matrix.

On the one hand, its dimensions are science, methodology, textbooks, computers, software, institution infrastructure, the training and retraining of teachers who are not competent in the field of computer technology. On the other hand, clearly defined forms and methodology of information and communication technology implementation to the educational process are no less important.

Therefore, the informatization of education is a complex process and the choice of the right strategy is crucial to its effectiveness and expediency. It is connected with the provision of education institutions' computerization, the creation of appropriate scientific and methodological support, the retraining of existing professionals and training of new ones in the field of vocational education, including computer engineering educators, new labour market conditions.

Academician Bykov (2014) emphasizes that the modern stage of social development is characterized by a significant increase in the role of knowledge - a leading productive factor of modern intellectual and spiritual development. This leads to the expansion and deepening of scientific research and experiment carried out in various sectors of society, at all levels. On this basis, the existing and emerging fields of knowledge, high-tech solutions (e.g. nano- and biotechnology, space technology, artificial intelligence, educational technology, health and agriculture technology, information and communication technology, etc.), and new highly intelligent automatic and automated high-performance tools are developed and created. According to the scientist, in order to solve the problems connected with the informatization of society, it is necessary to reform education and modernize future specialists' training content in different industries. First of all, it concerns the quality of graduates' information technology literacy, in particular, computer engineering educators, since the competition prevailing in the modern market of educational services increases the requirements for their professional training (Bykov, 2014).

Education informatization causes changes in its procedural component. Despite some conceptual differences in some issues of educational informatization, such researchers as Hershunskyi (1987) and Makarenko (2013) agree that the integration of information technology into the educational process in higher education institutions will promote its individualization, differentiation, intensification and, as a result, its optimization and improvement. According to Makarenko (2013), information technology potential as a support for the development of the student's personality is indispensable. It ensures their ability to think alternatively, 
to develop a strategy of finding solutions for both educational and practical problems, to predict the results of the implementation of decisions made based on the modeling of objects, phenomena, processes, relationships between them.

The use of information and communication technology in the study of the elements of science by engineering educators boosts educational process efficiency in terms of mastering the ability to acquire and retrieve knowledge, to master common cognition methods and the strategy of learning educational material, to make an independent choice of the educational activity mode, organizational forms, and teaching methods.

Information and communication technology in the educational process makes it possible to redirect the main teacher's assistance to make students solve creative, research, and problematic tasks (Makarenko, 2013; Nisimchuk, Padalka, 2013). Among the recent domestic studies on the development of information and communication technology in education, special consideration should be made of the collective monograph edited by Bykov (2010) in which particular attention is paid to the theoretical and practical issues of forming a common education information space.

Scientists Vdovychyn and Yatsyshyn (2013) point out that the informatization of education is an important component of modern society development. The creation of an open educational environment and formation of its tools and technologies which include modern information and communication technology and computer-oriented resources is a priority of open education (Vdovychyn, Yatsyshyn, 2013).

Therefore, changing goals and education content modernization have become a major driving force behind the process of vocational education informatization. All these global transformations require proper centralized coordination as, with the formation of the information society, the category "information" has become crucial and is one of the driving forces for the development of information, social, and socio-pedagogical systems.

Initially, the word "information" has appeared in Latin, and there was no Ukrainian equivalent up until a certain time. It was used exclusively in the sense of "idea, science" (Semenyuk, 1994). Yasinskyi (1999) concludes that "information" as a philosophical concept fulfills a double function: 1) ascertaining and recording the flow of information at a particular point in time; 2) the use of accumulated information as a retrospective function.

Morze (2003), one of the leading domestic scientists in the field of computer science, notes that the concept of "information" is one of original, primary, and unspecified ones. He interprets the term "information" as an explanation, presentation, awareness.

Information is considered today not only as a spiritual product. Information as a product can be compared to other assets of civilization. Information is an object of observation and, at the same time, it acts as "raw material" for the production of 
new information and material values (Dzhyncharadze, 1997). Therefore, the result of information production is messages, knowledge which become social information only when they are subjectified by material media.

In the process of information society formation, there arises a need to create information space in which citizens' rights to information and information resources will be implemented, and understanding the essence of the "information" concept and its variations as well as the importance of the role of new knowledge and information technology in the development of all social spheres, in particular in the field of vocational education. At the same time, global informatization as a social and historical phenomenon contributes to the development of a qualitatively new component in the human culture - the computerized information culture (Shkurba, 1989).

The philosopher Abdeev (1994) believes that in the process of the individual's information culture formation it is necessary to be guided by the idea that a computer is a tool that has decisively changed the process of scientific knowledge production due to the delegation of control functions to technological systems. In these circumstances, human thinking should be more focused on the creative evaluation of results. According to the author, the individual's creativity and intuition should be developed in interaction with the computer. The qualitative novelty of computer technology as a cultural and creative beginning lies in the fact that it significantly extends human cognitive capabilities (Abdeev, 1994).

The analysis of the problem under examination allows to conclude that the future computer engineering educator not only acquires knowledge and practical skills but also masters the accepted system of values in society, learns to use criteria and categories created by culture to evaluate events and phenomena for forecasting activity results (Gurevich, Kademiia, 2006). In such a way, information culture is formed. Therefore, information culture is now regarded as a necessary attribute and a product of education, as well as a tool of familiarization with different types of professions. Information culture in this professional aspect is based on the design and technological approach.

Considering the decisive role of society and vocational education informatization in the process of future computer engineering educators' professional becoming, we consider it necessary to specify the stages of such specialists' preparation for professional activity in the modern information society. They are the following: formation of information culture foundations, information and communication skills as well as psychological and pedagogical competence.

The first stage involves the formation of logic and algorithmic, conceptual, visual and system-combinatorial thinking; emotional and positive orientation to practical activity; objective attitude to the possibilities and expediency of the use of computers and information and communication technology in a particular situation; personal responsibility for decision-making and activity 
results based on the integration of design and technology as well as information activities.

The second stage involves information and communication competence formation in future computer engineering educators. Competence, including IT one, as the highest step in the formation of any personality, is a prerequisite for a creative search. As a necessary part of future computer engineering educators' professional development, it should prepare specialists for the organization of independent work, in particular, using Internet technologies, ability to apply information and communication technologies in their professional activity.

The third stage involves psychological and pedagogical competence development as a component of professional excellence. Academician Ziazun noted that professional competence forms its basis (orientation and professional knowledge are the backbone of high professionalism in activities ensuring the integrity of the self-organized system) (Ziaziun et al., 1997, p. 31).

Psychological and pedagogical competence as an integrative personal quality is based on the knowledge of professional, methodological, and psychological fields (Kuzmina, 1989, p. 89). It implies the development of a proportional set of professional, communicative, and personality traits in future engineering educators, assisting in educational activities and preparing them for the independent education process modeling.

Conclusions. The growth and complexity of social, economic, and professional information require vocational education professionals to regularly improve their qualifications and skills and be prepared for any changes in their professional activity being able to adapt quickly and effectively to new conditions, i.e. be mobile. The modernization of vocational education in the conditions of intensive development of the information society in Ukraine is aimed at the formation in future computer engineering-educators of the internal need to realize and generate innovative ideas, to provide conditions for our country to become a part of the international information space.

Prospects. In order to effectively address the outlined issues, there is an urgent need to identify ways of professional competence formation in computer engineering educators.

\section{REFERENCES}

Abdeev, R.F. (1994). Filosofiya informatsionnoy tsivilizatsii. Moskva: Vlados [in Russian].

Bykov, V.Yu. (2014). Osnovni kontseptualni zasady informatyzatsii osvity i holovna paradyhma pryideshnoho suspilstva znan. In: I.A. Ziaziun, O.M. Otych [et al.] (red.), Ya-kontseptsiia akademika Nelli Nychkalo u vymiri profesiinoho rozvytku osobystosti (pp. 32-42). Kyiv: Natsionalna akademiia pedahohichnykh nauk Ukrainy; In-t ped. osvity i osvity doroslykh NAPN Ukrainy [in Ukrainian]. Bykov, V.Yu. (red.). (2010). Zasoby informatsiino-komunikatsiinykh tekhnolohii yedynoho informatsiinoho prostoru systemy osvity Ukrainy. Kyiv: Pedahohichna dumka [in Ukrainian]. 
Dzhyncharadze, N.H. (1997). Informatsiina kultura osoby: formuvannia ta tendentsii rozvytku (sotsialno-filosofskyi analiz). Kyiv (Doctor's thesis) [in Ukrainian].

Gurevich, R.S., Kademiia, M.Yu. (2006). Informatsino-telekomunikatsiini tekhnolohii v navchalnomu protsesi ta naukovykh doslidzhenniakh. Kyiv: Osvita Ukrainy [in Ukrainian].

Hershunskyi, B.S. (1987). Kompyuterizatsiya v sfere obrazovaniya: problemy i perspektivy. Moskva: Pedagogika [in Russian].

Kuzmina, N.V. (1989). Professionalizm deyatelnosti prepodavatelya i mastera proizvodstvennogo obucheniya. Moskva: Vysshaya shkola [in Russian].

Machlup, F. (1962). The Production and Distribution of Knowledge in the United States. Princeton: Princeton University Press.

Makarenko, L.L. (2013). Pobudova merezhevoho informatsiino-navchalnoho seredovyshcha vyshchoho navchalnoho zakladu (teoretyko-metodychnyi aspekt). Naukova skarbnytsia osvity Donechchyny, 2(15), 27-32 [in Ukrainian].

Mikhaylevich, V.S. (1989). Informatizatsiya - vazhneyshiy resurs perestroyki chelovecheskogo obshchestva. Upravlyayushchie sistemy i mashiny, 2, 3-6 [in Russian].

Morze, N.V. (2003). Metodyka navchannia informatyky. T. 2: Metodyka navchannia informatsiinykh tekhnolohii. Kyiv: Navchalna knyha [in Ukrainian].

Nisimchuk, A.S., Padalka, O.S. (2013). Tekhnolohiia innovatsiinoi osvity. Lutsk: Tverdynia [in Ukrainian].

Ramskyi, Yu.S. (2002). Formuvannia informatsiinoi kultury maibutnikh vchyteliv matematyky ta informatyky. In: Kompiutery v navchalnomu protsesi. Proceedings of the Scientific and Practical Conference (pp. 57-58). Uman: Almi [in Ukrainian].

Robert, I. (1991). Novye informatsionnye tekhnologii v obuchenii: didakticheskie problemy, perspektivy ispolzovaniya. Informatika i obrazovanie, 4, 18-25 [in Russian].

Semenyuk, E.P. (1994). Informatsionnaya kultura obshchestva i progress informatiki. NTI, 7, 34-43 [in Russian].

Shkurba, V.V. (1989). Informatika i sociotehnika. Upravlyayushchie sistemy i mashiny, 2, 12-23 [in Russian].

Toffler, A. (1983). Previews \& Premises: An Interview with the Author of Future Shock and the Third Wave. New York: W. Morrow.

Vdovychyn, T.Ya., Yatsyshyn, A.V. (2013). Zastosuvannia tekhnolohii vidkrytoi osvity dlia informatyzatsii navchalnoho protsesu. Informatsiini tekhnolohii v osviti, (16), 134-140 [in Ukrainian].

Yasinskyi, A.M. (1999). Formuvannia osnov informatsiinoi kultury shkoliariv zasobamy intehrovanykh zavdan z informatyky. Rivne (Candidate's thesis) [in Ukrainian].

Yershov, A.P. (1988). Shkolnaya informatika v SSSR: ot gramotnosti - kulture. In: B.N. Naumov (red.), Informatika i kompyuternaya gramotnost (pp. 6-23). Moskva: Nauka [in Russian].

Zhaldak, M.I., Ramskyi, Yu.S. (2010). Shkilnii informatytsi - 25! Naukovyi chasopys NPU imeni M.P. Drahomanova, 8(15). 3-17 [in Ukrainian].

Ziaziun, I.A., Kramushchenko, L.V., Kryvonos, I.F. [et al.] (1997). Pedahohichna maisternist. Kyiv: Vyshcha shkola [in Ukrainian]. 


\section{STRESZCZENIE}

W artykule podkreślono wpływ informatyzacji edukacji na proces przygotowania zawodowego inżynierów-pedagogów o profilu komputerowym. Potwierdzono, że informatyzacja edukacji odgrywa obecnie rolę społeczno-kulturowego mechanizmu wpływu na kształtowanie się aktywnego, pełnego inicjatywy, mobilnego specjalisty w dziedzinie edukacji zawodowej. Ustalono, że wzrost i złożoność informacji społecznej, gospodarczej i zawodowej wymagają od inżyniera-pedagoga o profilu komputerowym umiejętności szybkiej i skutecznej adaptacji do nowych warunków na rynku pracy. Aktualizuje to społeczne zapotrzebowanie na celowe kształtowanie u przyszłych inżynierów-pedagogów o profilu komputerowym kompetencji informacyjno-komunikacyjnych, które zakładają osiągnięcie samodoskonalenia zawodowego, samookreślenia i samopozycjonowania.

Słowa kluczowe: informatyzacja edukacji; technologie informacyjno-komunikacyjne; inżynierzy-pedagodzy o profilu komputerowym; kompetencje informacyjno-komunikacyjne; kompetencje psychologiczno-pedagogiczne 